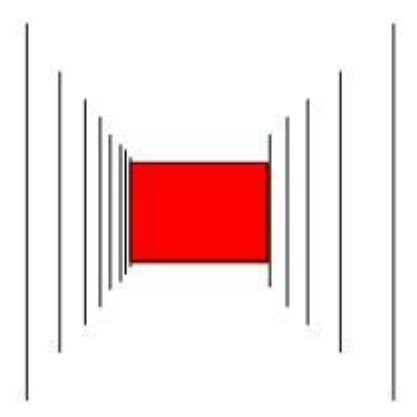
Centre for
Building
Performance
Research

\title{
Facilitating community gardening and urban agriculture.
}

\begin{abstract}
A systematic review of master planning strategies that bring about positive outcomes for the communal space.
\end{abstract}

Nilesh Bakshi

Fabricio Chicca

Andre Brown

Mark Fletcher

Research and publication by the

Centre for Building Performance Research, Victoria University of Wellington.

In partnership with:

Studio of Pacific Architecture.

March 2019 
Edition information

ISBN 978-0-475-12429-6

Authors: Nilesh Bakshi, Fabricio Chicca, Andre Brown and Mark Fletcher Partnering Researchers: The Research Group at Studio of Pacific Architecture

Report title. Facilitating community gardening and urban agriculture: A systematic review of master planning strategies that bring about positive outcomes for the communal space

Centre for Building Performance Research,

Victoria University of Wellington,

P.O. Box 600, Wellington, New Zealand.

Phone + 6444636200 Facsimile + 6444636204 


\section{Preface}

\section{Table of Contents}

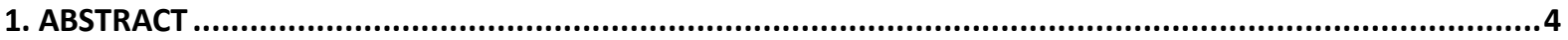

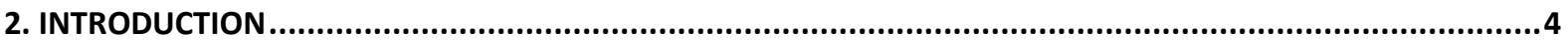

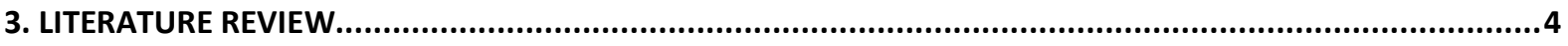

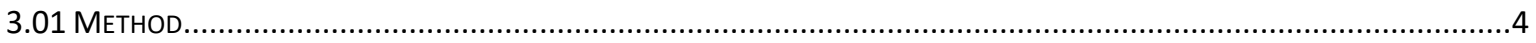

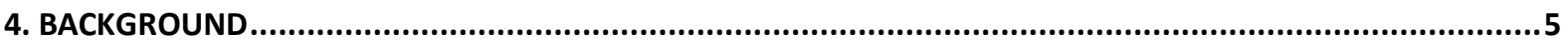

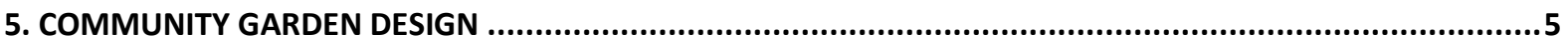

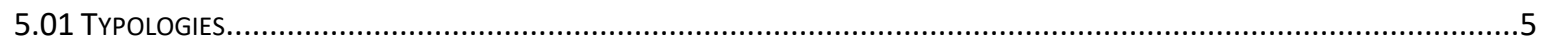

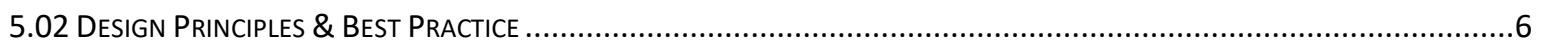

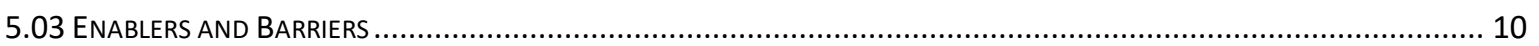

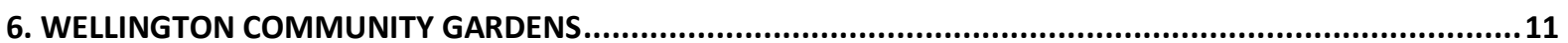

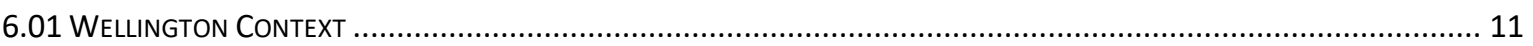

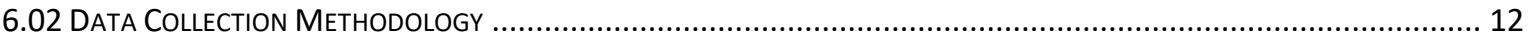

6.03 Review of Weluington City Council Community Gardening Policy ..................................................... 13

ASSESSMENT OF WELLINGTON COMMUNITY GARDENS...............................................................14

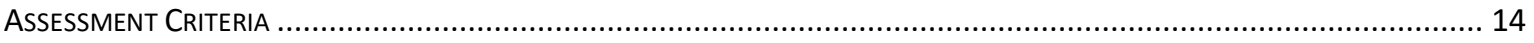

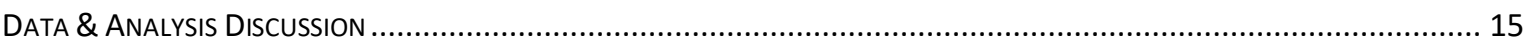

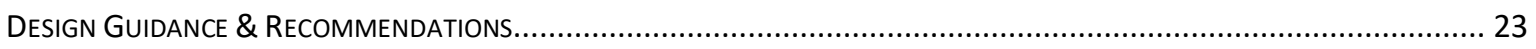

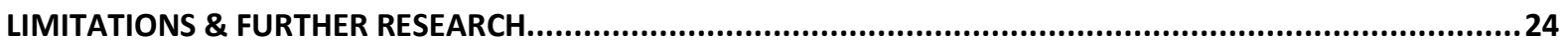




\section{Abstract}

This study researches the possibilities and best strategies to facilitate community gardens in Wellington, New Zealand. First, an investigation of literature uncovers the background on the benefits of community gardens as motives to initiate, participate and support them. A comprehensive look into the forms of design methodology for community gardening then outlines a framework of best practice that new gardening ventures may use as a guide to strive towards for a successful garden. Despite a comprehensive review of literature, there was still little data and information available of quantitative metrics to measure community gardens including food production, volunteer participation and funding/income. Without a measurable criterion, the success of the gardens cannot be measured against one another. Community gardens in Wellington were assessed as case studies against the design best practice framework, to understand how currently gardens and policy performed against international standards. They fell short, notably against scaling for population as well as maximising the efficiency of the sites. Policy for community gardens by Wellington City Council was also found to be one of the key barriers to the success of gardens, with policy dictating the limits of gardens, and contradicting their own statements between resilience frameworks and community garden design guides. To move forward to produce more successful community gardens in Wellington, a new framework is outlined to maximise design potential, as well as suggestions for further research that may refine the definition of a successful community garden.

\section{Introduction}

This report discusses how urban agriculture can be facilitated in New Zealand, more specifically, in Wellington. Urban Agriculture is growing in popularity across the globe, but we are only in the last decade have we seen it grow roots in Wellington. First, it is important to understand that urban agriculture (UA) is an umbrella term that describes any agricultural practice that occurs in urban and suburban areas. The key drivers behind agricultural urbanism is integrating food processes back into society due to the multiple benefits it can be seen to have. The concept of closing the food cycle connects people are to their food and eating, benefits to their health, economic benefits for local businesses, environmental sustainability and city or neighbourhood resilience.

Community gardening is one link in the urban agriculture chain, where a group of individuals from a local area form a joint gardening venture. Community gardens can be approached in a variety of ways, and often result as beneficial for the individuals involved etc. Community gardening should be seen as part of a web of processes and the term is not interchangeable with urban agriculture (CG is UA, but UA is not just CG).

\section{Literature Review}

\subsection{Method}

A narrative literature review was undertaken to develop an understanding of the existing research available on community gardens nationally and internationally. The narrative review method was chosen to obtain an understanding of current research on community garden and urban agriculture design, best practice and techniques that make for a successful garden. This review of literature was undertaken as a process, with 
each step building the platform for the next, where the next step in the research was not always clear until its predecessor was in process. This allowed the research to focus its Wellington case study on filling a gap in research, to form the assessment of the community gardens around connecting quantitative data to the quality of the gardens and the neighbourhood demographic.

The key terms of research were used to begin the sear process on databases, with a further refinement of the titles found from there. The key terms were as follows:

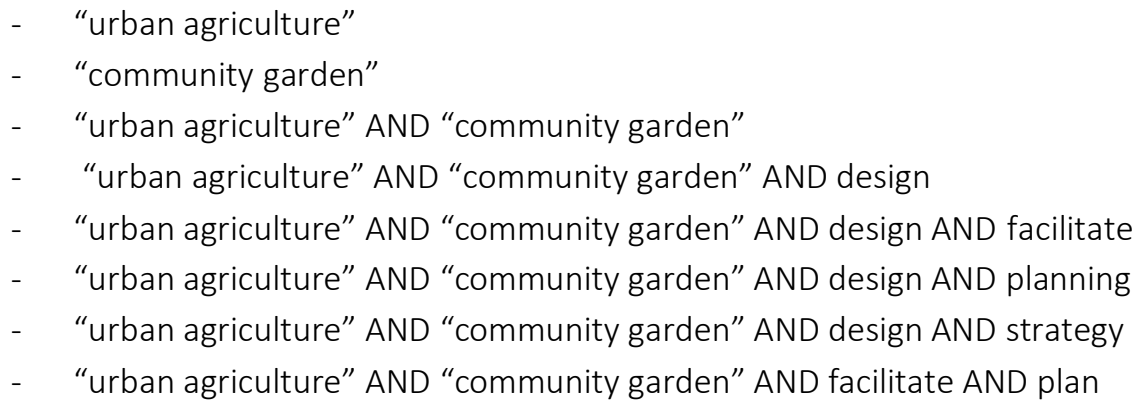

Literature was also sourced from local resources, resulting in 3 titles found and added to the study.

\section{Background}

Research on community gardens is still relatively new...? And mostly covers much of the benefits of community gardening and the positive results. Community gardening appeals to individuals due to its positive effect on the environment, health, communities and social stuff etc. with one or more of these positive outcomes being drivers for individuals to participate in it. Fewer research yet has been conducted nationally to investigate New Zealand's scenario.

\section{Community Garden Design}

\subsection{Typologies}

Community gardens can be found in a variety of forms, scales and operations which can be categorised into typologies.

\begin{tabular}{|l|l|}
\hline Typology & Description \\
\hline Allotment & $\begin{array}{l}\text { A set of garden plots in a public area where each is leased to an individual or family for personal use. } \\
\text { Generally, there is a fee involved in leasing the land parcel. Work done on the plot is carried out by the } \\
\text { individual leasing it while the harvests are then also for the individual's use. }\end{array}$ \\
\hline Community garden & $\begin{array}{l}\text { A group gardening venture cared for by a community or group of volunteers. They primary produce } \\
\text { vegetables as well as fruits, herbs and flowers. } \\
\text { Community gardens are typically found on public for the ease of access to a collective group. However, at } \\
\text { times they may also be found on private land where the owner of the land may be willing to allow its use as a } \\
\text { community garden. }\end{array}$ \\
\hline Community orchard & $\begin{array}{l}\text { Similar to a community garden where a gardening venture is cared for by a community or group of } \\
\text { volunteers producing fruit and potentially other forms of edible produce. }\end{array}$ \\
\hline
\end{tabular}




\begin{tabular}{|l|l|}
\hline $\begin{array}{l}\text { Institutional edible } \\
\text { garden }\end{array}$ & Gardening schemes initiated, run and utilised by institutions. \\
& Institutions may a work office, community group, church / religious centre, schools and university etc. \\
\hline Food forest & Agricultural ventures applied in a \\
\hline Guerrilla gardening & $\begin{array}{l}\text { This form of gardening involves individuals planting and caring for edible planting on public land without } \\
\text { formal permission to do so. This is typically at a smaller scale and tackles under utilised or vacant }\end{array}$ \\
\hline $\begin{array}{l}\text { Productive parks } \\
\text { as urban agriculture) }\end{array}$ & $\begin{array}{l}\text { City gardens are large scale gardening ventures that occur within or on the outskirts of urban areas. City } \\
\text { farms may produce a range of vegetables, fruits and herbs and may keep livestock such as chickens or bees. } \\
\text { Where are community gardens typically have a take what you grow policy, city farms are more likely to have } \\
\text { a controlled distribution } \\
\text { Due to their scale they may require a level of expertise, where there may be hired workers from the } \\
\text { government or other organisations to care for the farm. }\end{array}$ \\
\hline
\end{tabular}

In some cases, community gardens are initiated for as a specific way to ... Special cases of community gardens/urban agriculture that explore alternative approaches to the practice, not commonly seen - eg. Grow data youth farm.

Community gardens may also present a hybrid of two or more typologies.

\subsection{Design Principles \& Best Practice}

One outcome of the narrative literature review was being able to piece together principles and theory for designing integrated urban agriculture systems. Literature suggests strategies that can be implemented to improve the design of community gardens and urban agriculture at a city planning scale. The idea of an "improved" design pertains to the goal of maximising efficiency and therefore the impact of community gardens. The following design principles should be considered in urban agricultural design however this must work in conjunction with relevant enablers and barriers and site-specific context. Although most of these design guidelines are directed at community gardening, some relate to the broader scheme of urban agriculture. As suggests, for community gardening to be successful, it must be supported by urban agriculture elements.

The key for ua to be a success is for it to become normalised

Aims of Urban Agriculture (Janine de la sale \& Mark Holland)

Outlining what agricultural urbanism should adhere to (make a big cool infographicy thing that shows the key ideas of what urban agriculture should strive to achieve)

\section{Designing processes / scope}

Clarke et al speaks of a broad spectrum of practices that enable agriculture to be designed into the urban world. To achieve an integrated city, there is a need for UA to be intertwined with the city fabric and culture, rather than designed in isolation (existing or unbuilt) (P.141). Clarke suggests that most importantly, designing urban agriculture into society requires consideration of every facet of the practice, not only food production (ie. community gardens). To be able to promote a complete, localised system, a layered approach is important for a completed network and for each area to facilitate one another. The processes of urban agriculture stated are as follows: 
- Production: growing and harvesting of food

- Processing:

- Distribution

- Retail

- Consumption / celebration

- Waste recovery

- Education

In each area there is a list outlining various considerations for each urbanised system. Designing a whole system as opposed to individual reactions to urban agriculture can provide a stronger foundation for a city to grow their agricultural presence.

At the planning stages, Ransford ( $p 190$ ) emphasises the importance of public involvement and the need to use "community vision" as the key driver for the design. It is important that the UA of a locale expresses their unique values and needs in order to fully integrate the programme into the community. Developing the community vision may be a design processes in itself. Furthermore

\section{Site}

Site specific designing, site potential, site selection

Clarke et al (p122 AU book) outlines how food can be designed into the urban fabric, through working with an existing environment as well as one yet to be designed. Urban agriculture systems can be integrated into buildings, streets and open spaces to promote their function and create highlight it within a community environment. Clarke offers a variety of suggestions to maximise the opportunities, which have been summarised in the table

\begin{tabular}{|c|c|}
\hline SPATIAL TYPE & URBAN AGRICULTURE SITE POTENTIAL \\
\hline Buildings & $\begin{array}{l}\text { - } \quad \text { Designing buildings with UA support facilities - greenhouses, wastewater treatment, energy supply } \\
\text { - } \quad \text { Architectural aesthetic to reflect UA } \\
\text { - } \quad \text { Building façades that aid visual connection to food processes within and outside buildings. Alternatively, } \\
\text { building facades that grow food on the walls (interior or exterior } \\
\text { - } \quad \text { Roof tops* utilising space for growing at various scales - from garden to just a few plant boxes; new } \\
\text { design can design for a larger scale with the necessary infrastructure. }\end{array}$ \\
\hline $\begin{array}{l}\text { Street-scapes / Travel } \\
\text { areas }\end{array}$ & $\begin{array}{l}\text { STREETS } \\
\text { - } \quad \text { Designing connections to food*, so that every person lives within a } 10 \text { minute walk to food. Removing } \\
\text { the need for reliance on vehicles/ other forms of transport } \\
\text { - } \quad \text { Productive edible landscapes* where plants along the streets bare fruits or nuts. Can be introduced in } \\
\text { existing parks or planters added } \\
\text { - } \quad \text { Designing places to eat and drink - exposing the public to eating } \\
\text { - } \quad \text { Pedestrian orientated streets that supports pedestrian movement } \\
\text { - } \quad \text { Designing spaces to support local businesses along the street - ie gardens that may supply to local } \\
\text { - } \quad \text { restaurants } \\
\text { - } \quad \text { Creating habitats for pollinators improves the environment's suitability for food processes } \\
\text { - Storm water systems that can harvest and reuse run iff water for UA practices. } \\
\text { - Green street designs that fully integrate UA practices as well as infrastructure and combining park and } \\
\text { street elements into one. } \\
\text { Transparency of streetscape* allowing people to see into food processes. Eg. Using permeable fences } \\
\text { around community gardens. } \\
\text { Signage* - to signal agricultural practices and educate }\end{array}$ \\
\hline
\end{tabular}




\begin{tabular}{|c|c|}
\hline & $\begin{array}{l}\text { GREENWAYS } \\
\text { - } \quad \text { Using green corriders to link together a diverse UA network } \\
\text { - } \quad \text { Planning walking and cycling trails/tours to intersect UA or vice versa. The tours themselves may also } \\
\text { promote local agricultural practices eg urban farm tours. } \\
\text { - } \quad \text { Building greenways to accommodate the required foot traffic (pedestrians and cyclists) as well as } \\
\text { support any machienery or small vehicles } \\
\text { - Designing resting spots or picnic areas on these trails to connect people with food eg. Locataing them } \\
\text { with produce } \\
\text { Using greenways as community garden sites to connect communities together. Furthermore, the } \\
\text { landscape setting itself can be productive } \\
\text { Food programmes in green corridoors need to work with the exisiting ecosystems in place } \\
\text { - Agricultural art instiallations } \\
\text { - Signage, as above } \\
\text { - Stormwater as above }\end{array}$ \\
\hline Parks and Open spaces & 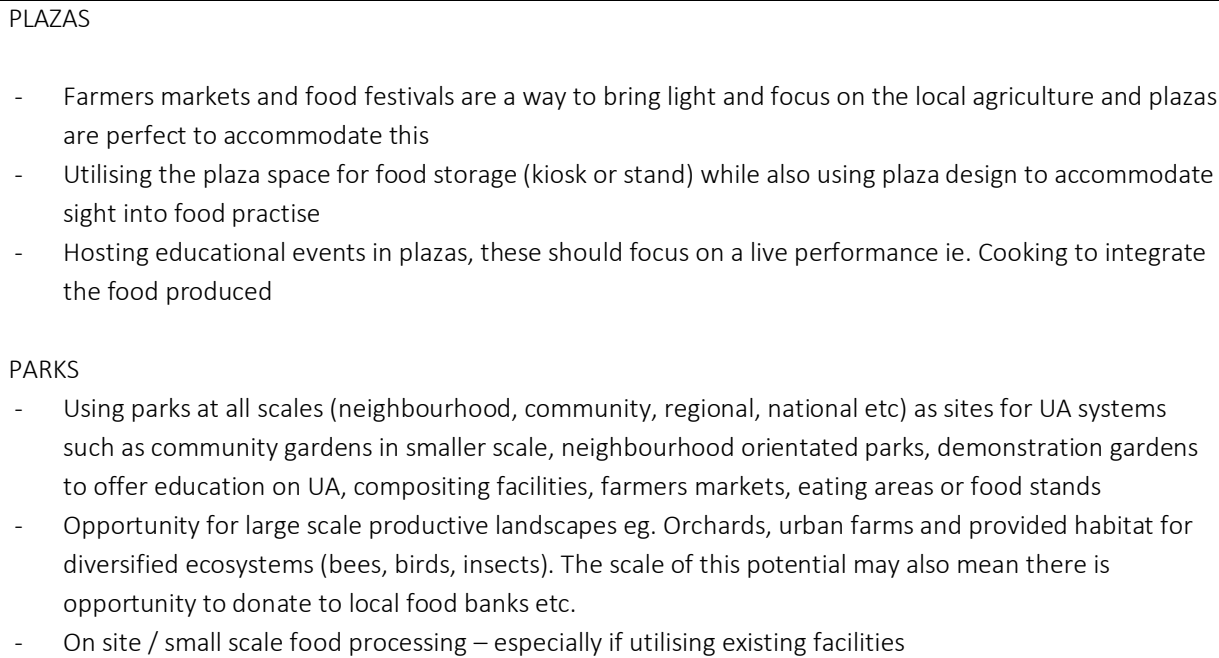 \\
\hline
\end{tabular}

The location of the site should also consider the five-minute rule. A community garden should be approximately within a five-minute walking distance from the targeted community it is providing for. Designing within the 5-minute rule creates convivence of access, with the theory that an individual in most likely to choose an option that is most convenient for their circumstance. For example, if it takes a person 5 minutes to walk to a convenience store versus 20 minutes to walk to a community garden, it would be more convenient for them to choose the shorter walk. In designing to community gardens or distribution outlets in a 5-minute walking distance from the target community, it creates an accessible option for local produce to be convenient.

The structure of urban agriculture works with the concept of a local system, supported by pedestrian access and visibility from pedestrian routes. Also people need to be able to carry home their produce.

In the case of existing gardens:

If a community is already established in the local vicinity of a considered site, the scale of the existing and prospective gardens should be considered before the second is designed (see below for guidance). Factors of the existing garden such as condition and use should be considered before a new garden is designed. For example, if an existing garden is in a poor or deteriorated condition, reasons why should be considered - is there an interest or desire for community garden in the area? Should this garden be refurbished or moved as opposed to creating a second. If an existing garden thrives in its current location, expansion or additional facilities could be explored to further improve the garden.

Visibility 
Scale

Multiple contexts that discuss the human scale that urban agriculture should be. Walking distance, easy to interact with, local,

It should be scaled so that the system can rely solely on the participation of the local neighbourhood, without the need for additional help (Ransford, p188) (this should be inclusive of all 7 facet of the UA system). Should not rely on transport etc. Human scale agriculture provides people with experience that can aid understanding, interest and participation in UA as opposed to big industry where processes are removed from the public realm.

Scale of garden size for the population density of the area

Further recommendations for each scale of gardening venture (diagram)

The appropriate scale of a community garden may also dictate the garden typology to inform the design. The various forms of garden typologies and management typologies should be matched to their individual communities to ensure the productivity/function of the garden space

Integrated infrastructure / maximising sustainable potential

Integrating infrastructure systems into urban agriculture and community garden design schemes are essential for improved function of the site, especially in larger scale schemes. Fraser notes the crucial role that infrastructure plays and the specialised systems that urban agriculture may require, but by through integrative design more efficient designs can be achieved that can ultimately improve the function and performance of the facilities.

Concerning - water supply, storm water drainage, sewage management, transport, energy

Green reuse, composting

Demographic Factors

There is a gap in research focusing on the relationship between a community demographic and a community garden. The effects of demographics such as age, income, density, population and employment on community gardening ventures would be an interesting area to further look into to assist future design. For example, gaining a comprehensive understanding of what typologies of gardens best suit various communities and how design can tailor the gardens to their communities. Best practice design for individual communities.

Density and house typologies

Land ownership

Social networks

Institutional support structures

Food security and safety

Cultural influences and traditions

Policy design:

Peter Lander (P. 172) discusses how public policy can support urban agriculture. The key elements that provide the most support to the sector are:

- $\quad$ Easy access to land (parks, schools, vacant lots)

- Free water

- Distribution, storage and processing hubs 
- Public institutional purchase of neighbourhood food

- $\quad$ Free compost (preferably delivered)

\subsection{Enablers and Barriers}

Community gardens are affected by a variety of variables that can become enablers or barriers, depending on their treatment and context. These variables are much like a set catalyst but can affect the success of the garden and thus it is important to pay attention to these when designing community gardens. The catalysts can be broken down into the following categories; policy, environment, management, funding and participants. For a community garden to be successful it is essential for the design to consider its unique scenario and design solutions around these catalysts.

Extraneous variable

Policy

Having policy that not only supports but encourages urban agriculture is essential for it to reach a scope of impact in a community. A study on policy effecting community gardens in Edinburgh discusses how local food growing fits into multiple policy sectors including: health, environment, agriculture, business, land use and planning and social well-being as they are a way of contributing / delivering a wide range government objectives (Witheridge and Morris, 2016). Community gardens are supported thorugh out a combination of sectors, needs to be on a local and national scale, consistency

Policy as a barrier or enabler to community gardens will be a unique scenario

Because community gardening fits into a wide range of policy, especially with funding,there is pressure to align to these agendas.

Refer to Cuba where they just did it and policy adapted to what the people wanted.

\section{Management}

- Bottom down / top up approaches

- Management structure and vision - management can weaken from varying ideas etc and interactions and relationships with local government etc.

Funding

- Processes of getting Monday may force a change in values (depending on the funding system)

- Also if they are making money that they are able to put back into the garden and how this might balance out - eg selling foods to local restaurants etc vs how much is reserved for the volunteers etc. equilibrium must be met to keep garden afloat

Environment / Site / Physical qualities

- Obtaining a site and challenges with zoning, land use policy, leases and more.

- Sun/wind/rain - physical access due to surrounding buildings etc

- Soil qualities

- Facilities in place - access to water etc, waste management, composting

- Climate and growing of seasonal foods

- Access, visibility and aesthetics 
Participants/community

- Perception

- Vision

- Demographic etc.

Participation in community members in a garden is vital in order to run and maintain a community garden (considering its typology requires this). A survey conducted in the Wellington suburb Eastbourne looked at the perceptions residents had on edible gardening. Urban edible gardening pertained to any form of gardening of vegetables, fruits and herbs; including but not limited to: home gardens, community gardens, berm gardens etc. They concluded from this study that for these users, the main barrier that prevented them from participating in gardening were their own perceptions about gardening. Their beliefs on having the skill, abilities, time and knowledge trumped barriers over the physical environments they had available for gardening. Interpreting this, we could use this study to understand that concerns surrounding community garden must be broken down to promote it within a community. Some strategies to tackle this could include regular educational workshop days, online resources, physical resources ie. Instructional signs. Furthermore, concerns included time and cost of gardening could be further mitigated by government support through funding and the shared responsibilities of gardening as a group.

Technology as an enabler (lander P173)

Vertical farming for maximising space and improving efficiency

\section{Wellington Community Gardens}

\subsection{Wellington Context}

Wellington City Council acknowledges 16 established community gardens in the Wellington City area (reference). This list is limited to gardens situated on public land and available to all locals, but many more community gardens can be identified within schools and institutions. The gardens are scattered across the city in multiple suburbs (see figure). The following table lists the gardens and provides a description of the case study gardens in Wellington.

\begin{tabular}{|l|l|l|}
\hline GARDEN & TYPOLOGY & DESCRIPTION \\
\hline Brooklyn Community Garden & Community garden & \\
\hline Houghton Bay Community Garden & Community garden & \\
\hline Innermost Gardens & $\begin{array}{l}\text { Community garden } \\
\text { and allotments }\end{array}$ & \\
\hline $\begin{array}{l}\text { Island Bay / Berhampore Community } \\
\text { Orchard }\end{array}$ & Community Orchard & \\
\hline Kai o Te Aro & Community Garden & \\
\hline Karori Community Garden & Community Garden & \\
\hline $\begin{array}{l}\text { Mokai Kainga (Owhiro Bay Community } \\
\text { Gardens) }\end{array}$ & $\begin{array}{l}\text { Community Garden } \\
\text { and allotments }\end{array}$ & \\
\hline Newtown Community Garden & Community Garden & \\
\hline Te Kawakawa Commons & & \\
\hline Thurleigh Grove (Workerbe Oasis) & Community Orchard & \\
\hline Kaicycle (Workerbe Oasis) & Community Garden & \\
\hline
\end{tabular}

Community gardens have not been evident in Wellington for very long, blab la bla Community garden history in wellington 
Cultural connection to Maori?

The purposes of this data collection and analysis is gage a better understand the communities that are choosing to initiate gardens in Wellington, build the future of wellington's community gardens. If there are connections between the demographics of the communities and the gardens, it starts a new conversation on how this can be used to facilitate gardens in the future. Futhermore, if we can correlate factors that contribute to the success of a garden...?

\subsection{Data Collection Methodology}

\section{Case study selection}

The case studies selected for analysis were chosen from the list of established gardens, provided on WCC's website. Restricting analysis to these gardens ensures the council's recognition and affiliation with each, implying financial support and that all gardens have adhered to the provided design guidelines. This is also guaranteed an equal opportunity for collecting data from local government. Only 11 of the initial list of 16 gardens were included in the review, due site accessibility and appropriateness of the garden as detailed in table (see table).

\begin{tabular}{|l|l|}
\hline Garden & Reason for no inclusion \\
\hline Bond Street Garden & $\begin{array}{l}\text { Bond Street Garden is described as a display garden (reference) and because of this did not } \\
\text { function in the same manner as the other gardens... }\end{array}$ \\
\cline { 1 - 2 } Khandallah Community Garden & $\begin{array}{l}\text { These gardens were excluded due to the logistics of site visits in the limited time frame of this } \\
\text { research. }\end{array}$ \\
\hline Northern Community Gardens & Due to the location of this garden on what once was a prison, limited information was available \\
\cline { 1 - 2 } Tawa Community Gardens & about the demographics of the area and also minimal "urbanisation" actually falls within \\
\hline
\end{tabular}

\section{Observational data}

Observational data was obtained through site visits to each of the 11 case studies. Observational recordings were required to inform areas that were not otherwise recorded or available. It was also crucial to see the current state of the gardens - as opposed to photos provided that may that may no longer be accurate depictions. Data categories that were considered observational included: Land area measurements, garden condition, terrain, composting facilities, types of garden beds, street visibility and signage. The garden condition, visibility and signage were documented through photographs as evidence against the situation at each date.

\section{Meshblock and Cencus Data}

Meshblocks are a tool used to section land area of New Zealand to easily identify information within each area. Meshblocks are not of standard sizing and geometries typically follow the established infrastructure (roads, boundaries etc.). Each meshblock has an identification number where Cencus NZ data can be found for each specific area. Cencus data collected in 2013 was the only data available that would be able to provide a full data set.

This tool was used to understand the demographics of the communities of the identified case study gardens. Each garden was located and a circle of 400m radius was drawn around each central point to identify the region that was within a 5-minute walking distance of the garden. From there, the meshblock ID numbers within this radius were collected. Due to the complex geometries of the meshblocks, there were often cases where meshblocks were both within and outside of the $400 \mathrm{~m}$ radius (see appendix for 
full meshblock data). With these cases, meshblocks that had the majority of their area within the radius were included and those with the majority of their area outside of the radius were excluded. Collecting each meshblock identification number allowed data to be found pertaining to each area, allowing us to collect demographic data on the regions with access to community gardens.

Additional information such as funding and vision statements were collected through publicly accessible webpages

\subsection{Review of Wellington City Council Community Gardening Policy}

Wellington City Council (WCC) supports but does not initiate community gardening ventures around the city. Community gardens in Wellington are typically established in a bottom-up approach, where groups propose their community garden to Wellington City Council, who's role is to provide land, support and funding (reference). WCC assesses prospective gardens against a set criteria (figure).

Extractions from CG guidelines.

Language used in the guidelines indicates that WCC has a narrow perception of community gardens and does not show understanding of the range of typologies and potential of community gardens. WCC defines community gardens as "a small-scale, low-investment neighbourhood communal gardening venture, where the primary purpose is growing vegetables or fruit"; but by using limiting terms such as 'small-scale' and 'low-investment', the language begins to limit the possibilities of community garden ventures. The design criterion further reinforces the WCC limited perception of community gardens. The guidelines discuss community gardens as additions to spaces and indicates that they are not perceived to have the potential to be the primary function or purpose of a space. The guidelines propose that alternative locations should be considered (to public open space), highlighting the view that public space should maintain its current qualities. Dictating that community gardens are not the purpose of a space is a limitation (without the consideration of what a community may actually desire).

Clarity of guidelines

The guidelines and assessment criteria of the WCC community garden guidelines are vague, which limits potential for each garden in their unique situation. Terminology used should be clearly defined and further elaboration on key terms used throughout the document should be provided in to assist those designing gardens. Key terms to be defined/redefined:

Urban agriculture: With community gardens being just one facet in the web of UA, defining UA and providing context should be considered in the document.

Community garden: A clarified description of community gardens without limiting word use would be beneficial to promote the creation of these spaces. Furthermore, outlining the typologies of community gardens could assist with the design process

Open space: open space is a broad term which covers a variety of spaces. Discussing this and then using more specific terminology and having specific guidelines for different open space types may potential open up more potential for community gardens. For example - a vacant lot is not the same type of open space as a public part. Community members see and use these space different this should be accounted for in the guidelines i.e. you would not need to retain the open space quality of a vacant lot in the same way you may want to with a park. Define the different types as outlined on council map 
Although WCC provides an assessment criterion, there are no other resources that may assist in the design of community gardens. Inclusion of suggested best practice principles, operational styles and

\section{OPEN SPACE STUFF FROM BELLA}

Evaluating WCC's guidance implied perception of community gardens by the council is inconsistent (contradicts?) with what is outlined on the city's resilience plan. Their vision states "a resilient city which integrates urban agriculture into the urban form, infrastructure and out communities" (Growing our city). Detailed in section 1.2, Community Resilience, community gardens are nominated as a methods to support community space for wellbeing and post-disaster roles (p. 52) but mostly as a strategy to develop sustainable food networks (p 53) (Council, n.d.). The urban agriculture programme will expand and partner with existing organisation to support those in need and establish community garden programmes in association with them. However, public community gardens are not initiated by WCC but individuals / community groups

The disassociation between aims and visions of the resilience strategy and design highlights where the council's strategy has not been put into use. Its use as a strategy but fails to initiate them and language used limits growth. Confusion, lack of serious commitment to utilising them as a resource. Council limitations could be driving bad design decisions through their language and selection process - street visibility, sunlight, space allocation, terrain. Furthermore, it is unclear how community visions are harnessed in designing community gardens and how unique community visions may align to WCC's guidelines or to the City Resilience strategy.

"makes more local food available" yes but looking at how you promote CG it won't actually be supplementing that much more food into the community in the event of a disaster.

The council guidelines are vague and creates a set list of assessment criteria without defining open space etc. multiple types of open space can be identified.

\section{Assessment of Wellington Community Gardens}

\section{Assessment Criteria}

1. Visual Analysis

2. Gardens around the city / scale of operation

3. Individual studies of gardens

4. Demographic Comparison

5. Are there any trends we are seeing purely where communities are initiating their gardens

6. Physical Comparison

7. Conditions, sizes, etc how is each garden comparing to one another?

8. Data Analysis

9. Further comparing throughout the demographics

a. QUANTIFYING MONEY - money per productive $\mathrm{m}$ squared, per population supposedly using the garden, bigger garden more money? More money better quality? So many questions and opportunities u know. 


\section{Data \& Analysis Discussion}

The following section analyses the Wellington community garden case studies against the knowledge obtained on best practice of UA design (section $\mathrm{x}$ ). Thorough analysis of the physical gardens, community demographics and policy will provide insight to guide Wellington-specific design in the future.

\section{Policy Analysis}

As discussed in section _, the alignment of visions between council, gardens and community are one of the key enablers or barriers to the success of the gardens. It is essential for the garden to balance their set of objectives with the needs of the broader community and the aims of local government. Vision statements embody the core ideas and values as the drivers of the community garden. It may also be presented as a goal that the gardens strive towards. In Wellington, 9 of the 11 case study gardens had a recorded vision statement on their website and/or social media (table).

\begin{tabular}{|c|c|}
\hline Garden & Statement \\
\hline WCC Vision Statement & $\begin{array}{l}\text { Develop sustainable food networks (page 53) } \\
\text { Lead by WCC, Partnering with Food distribution network \& Sustainability Trust } \\
\text { "This project will teach potentially vulnerable Wellingtonians how to grow food for their own use and to } \\
\text { establish small businesses. This can support their physical and mental health, wellbeing and provide a } \\
\text { new source of income (Projects } 1,2,10 \text { ). The project provides an opportunity for refugees, aged or } \\
\text { other people disconnected from the wider society to integrate back into their neighbourhoods (Project } \\
\text { 3). } \\
\text { It also makes more local food available in an event where Wellington has reduced connection with the } \\
\text { rest of the country (Project 18)." } \\
\text { Community Gardening guideline: } \\
\text { "A community garden is generally defined as a small-scale, low-investment neighbourhood communal } \\
\text { gardening venture, where the primary purpose is growing vegetables or fruit." }\end{array}$ \\
\hline Brooklyn CG & No statement available \\
\hline Houghton Bay CG & No statement available \\
\hline Innermost Gardens & $\begin{array}{l}\text { "Our mission is "Growing community through hands in the soil", so whether your passion is growing } \\
\text { food, strong communities, permaculture design or sustainability, we've got what you may be looking } \\
\text { for to get your taste buds active, your mind intrigued or your hands dirty." }\end{array}$ \\
\hline Island Bay / Berhampore CO & $\begin{array}{l}\text { "We are a Community Trust that is working to establish an urban orchard where anyone can come } \\
\text { along and pick and enjoy fresh, organic, wholesome fruit." }\end{array}$ \\
\hline Kai o Te Aro & $\begin{array}{l}\text { "She says a main aim of Kai o Te Aro is "building community and giving people confidence", by } \\
\text { educating each other on how to best grow things in Wellington, as well as things such as permaculture } \\
\text { and seed saving. In their three garden sites, they have planted a variety of vegetable and herb plants as } \\
\text { well as fruit trees" } \\
\text { "The whole point of it really is to start co-op gardens where people can work alongside each other, } \\
\text { learn about growing vegetables, seed saving, building compost, worm farms and getting rid of food } \\
\text { waste," she says. } \\
\text { "It has a strong environmental message, but it also emphasises that you don't need a huge area to } \\
\text { grow gardens. A lot of people grow herbs in pots, and there are a lot of apartments around here that } \\
\text { are developing roof gardens-I think that's a great idea." }\end{array}$ \\
\hline Karori CG & $\begin{array}{l}\text { The KCG is a non-profit, community-based organisation. The primary aim is to establish and maintain a } \\
\text { community garden in Karori to enable KCG members to grow food in a sustainable manner. } \\
\text { Other aims of the KCG include: } \\
\text { to provide a safe and enjoyable place for people, particularly children, to learn about } \\
\text { food gardening; } \\
\text { to meet other members of the Karori and wider Wellington community; }\end{array}$ \\
\hline
\end{tabular}




\begin{tabular}{|c|c|}
\hline & $\begin{array}{l}\text { to exchange knowledge and skills with others; } \\
\text { to hold regular 'working bees' to ensure the garden is well-maintained and improved over time and } \\
\text { to enable KCG members keep in face-to-face contact and discuss aspects relating to the garden. }\end{array}$ \\
\hline Mokai Kainga & $\begin{array}{l}\text { Community Gardens: a long-standing initiative that focuses on good nutrition, physical activity, learning } \\
\text { new skills including sustainable practices and caring for the environment. Importantly, the Gardens } \\
\text { have become a valuable social enterprise for } 16 \text { hanau within our community. }\end{array}$ \\
\hline Newtown CG & $\begin{array}{l}\text { A group for community gardeners interested in establishing and developing edible (and beautiful) } \\
\text { gardens in Newtown (Wellington). For the moment we are based at Carrara Park (access from walkway } \\
\text { at } 107 \text { Daniell Street, and end of Regent Street). We will use this group to communicate about events } \\
\text { and share relevant information to make the gardening a success. }\end{array}$ \\
\hline Te Kawakawa & $\begin{array}{l}\text { We are a small community garden, orchard and forest restoration group with a vision to create a haven } \\
\text { for birds, insects, children and families to enjoy and be safe. }\end{array}$ \\
\hline Thurleigh Grove & $\begin{array}{l}\text { Workerbe Oasis was started in } 2015 \text { with two sites- Thurleigh Grove and the site at } 5 \text { Hospital Road in } \\
\text { Newtown. The idea is to provide fresh, nutritious produce to the community through various initiatives } \\
\text { as well as provide a backdrop for action learning. } \\
\text { Kaicycle was started to collect the food waste that is going into landfill rather than compost and the } \\
\text { earth. } \\
\text { Now combined into the Society we seek to eliminate waste and gain more spaces to grow food. }\end{array}$ \\
\hline Kaicycle & $\begin{array}{l}\text { Our approach is permaculture based which means that the soil is regenerated through the use of } \\
\text { compost, bio-char and plant matter. We don't rely on chemicals to prop up poor soil, but instead focus } \\
\text { on the long game. This makes for hardier plants, fewer pests and delicious produce. We test our soil } \\
\text { and measure our output, looking for technical performance and yield. } \\
\text { Our work reconnects people to green spaces, to the natural rhythms of the seasons and to each other. }\end{array}$ \\
\hline
\end{tabular}

Although we have these available, we do not yet have information on what community members as a whole look for in a garden. Typically, gardens are created from a small group within a community and it is their vision/dream but how do we know if this is catering to a wider audience.

Three key themes reoccur within the community garden vision statements: growing fresh produces, sustainability and community. Wellington city council however have two statements. The first from the WCC community garden guidelines states the primary purpose is "growing vegetables or fruit", a produce focused goal. On the other hand, the resilience strategy aims for the

Innermost Gardens is an example they have a broad vision statement, which may be a strategic method of aligning themselves in any way possible -

Without further research, it is *unable to determine if these vision statements are genuine or if gardens may have experienced similar pressure to those in study to adjust their statements for funding. Or if they are reflecting the desires of a community rather than a small collectives.

\section{Physical analysis}

As seen in figure, community gardens are sparsely distributed across Wellington city. The outer radius indicative of a $400 \mathrm{~m} / 5$-minute walk to the garden in the centres. Looking at the coverage of gardens on this map, not everyone has access to a community garden within walking distance of their homes or offices. It is also important to consider that due to the scale of these gardens, that the populations within each of the walking radii may even get adequate use and produce from their allocated garden.

It is also important to note that all existing community gardens fall within suburban areas rather than the central urbanised area. Seeing as these projects are driven by communities this may be a result of siting opportunities, community engagement opportunities, convivence. The siting of gardens are acting inversely to their need, where communities more densely populated are not looking to food alternatives. 
The need for UA may also be alleviated by opportunities provided in the central area - farmers markets, lifestyle of eating out/easy access to food everywhere, and a difference in lifestyle.

Topography surrounding the gardens should also be considered. Where on the flat, a 400m walk is achievable while carrying produce however this may be less appealing to those in steeper terrain areas...?

In relationship to Wellington City Council's resilience strategy, from the number of gardens alone, community gardens is not yet strong enough to be considered 'resilient' in the sense it would be able to supplement food consumption in the event of a disaster. As seen, much of the population does not have access to a community garden. Ideally, the entire populated area would have at least one community garden within walking distance filled meaning all populations of of populated urban / suburban areas have access to a community garden within walking distance. Again, these gardens may not be of adequate scale to supplement the diets of the full populations thus it would be reasonable to continue initiating gardens within these areas too.

Figure 1: Locations and walking radii of community gardens in Wellington

\begin{tabular}{|c|c|c|c|c|}
\hline GARDEN & $\begin{array}{c}\text { TOTAL AVAILABLE LAND } \\
\text { AREA }\left(\mathrm{m}^{2}\right)\end{array}$ & $\begin{array}{c}\text { PRODUCTIVE LAND } \\
\text { AREA }\left(\mathrm{m}^{2}\right)\end{array}$ & $\begin{array}{c}\text { \% PRODUCTIVE LAND } \\
\text { AREA }\end{array}$ & $\begin{array}{c}\text { AREA AVAILABLE PER } \\
\text { PERSON }\end{array}$ \\
\hline $\begin{array}{c}\text { Brooklyn Community } \\
\text { Orchard }\end{array}$ & 1200 & & $28 \%$ & 0.04 \\
\hline $\begin{array}{c}\text { Houghton Bay } \\
\text { Community Garden }\end{array}$ & 220 & 62 & $11 \%$ & 0.11 \\
\hline Innermost Gardens & 3250 & 367 & $30 \%$ & 0.19 \\
\hline $\begin{array}{c}\text { Island Bay / Berhampore } \\
\text { Community Orchard }\end{array}$ & 1323 & 7.5 & $0.3 \%$ & 0.001 \\
\hline Kai o Te Aro & 1900 & 27 & $22 \%$ & 0.01 \\
\hline $\begin{array}{c}\text { Karori Community } \\
\text { Garden }\end{array}$ & 121 & & \\
\hline
\end{tabular}




\begin{tabular}{|c|c|c|c|c|}
\hline $\begin{array}{c}\text { Mokai Kainga (Owhiro } \\
\text { Bay Community } \\
\text { Gardens) }\end{array}$ & 4146 & 1130 & $27 \%$ & 0.76 \\
\hline $\begin{array}{c}\text { Newtown Community } \\
\text { Garden }\end{array}$ & 2950 & 57 & $2 \%$ & 0.01 \\
\hline Te Kawakawa Commons & UNKNOWN & & & \\
\hline $\begin{array}{c}\text { Thurleigh Grove } \\
\text { (Workerbe Oasis) }\end{array}$ & $840^{*}$ & & & \\
\hline $\begin{array}{c}\text { Kaicycle (Workerbe } \\
\text { Oasis) }\end{array}$ & $1250^{*}$ & & & \\
\hline
\end{tabular}

\section{Scale}

As seen in table, the scale of community gardens within wellington vary greatly from small ventures such as Kai o Te Aro to well established gardens such as Mokai Kainga. The proportion of land utilised as productive is all below one third of the land available. These fall short of the productivity of how a site may be utilised as a community garden, assumed to be $75 \%$ of space allocated for planting and $25 \%$ allocated for accessibility and tool areas. This figure assumes that the total land available is also to use is granted that use. Kai o Te Aro, for example, has a particularly low percentage of productive land, however it does so in abiding by WCC's guideline. The garden is situated in Aro Park, a pocket of open space with few trees and 3 picnic tables. The park does not appear to have a particular function with no play areas and minimal seating, and a short-cut pathway dissecting it at the centre. Following WCC's suggestions, all planting is located on the rims of the park in raised beds, but the open space qualities are maintained in the underutilised park. In all cases, it is unclear if under-utilising land is a result of the WCC's guidelines or if it may be a combination of a number of factors such as funding needed to make the land productive, the amount of community garden participants

Community garden land productivity is not capped by the scale of the garden. Potential areas to look at to remedy this may include more efficient site plans to maximise planting space while maintaining adequate circulation, revisiting the guidelines and their ideas of maintaining open space etc, strategic planting

Much like the number of community gardens around Wellington, the scale of productive space would not be able to support their allocated populations ( $400 \mathrm{~m}$ walking distance) in the event of a disaster. What would the ideal population number be for each garden considering their sizes?

\section{Quality of Gardens}

\begin{tabular}{|c|c|c|c|c|c|c|c|c|}
\hline GARDEN & $\begin{array}{c}\text { GARDEN } \\
\text { CONDITION }\end{array}$ & $\begin{array}{c}\text { GARDEN } \\
\text { TERRAIN }\end{array}$ & $\begin{array}{c}\text { SURROUNDI } \\
\text { NG TERRAIN }\end{array}$ & $\begin{array}{c}\text { COMPOSTING } \\
\text { FACILITIES }\end{array}$ & $\begin{array}{c}\text { GARDEN } \\
\text { BEDS }\end{array}$ & $\begin{array}{c}\text { STREET } \\
\text { VISABILITY }\end{array}$ & SIGNAGE & $\begin{array}{c}\text { FUNDING } \\
2018(\$)\end{array}$ \\
\hline Brooklyn CG & POOR & SLOPED & STEEP & YES & RAISED & NONE & POOR & 0 \\
\hline $\begin{array}{c}\text { Houghton Bay } \\
\text { CG }\end{array}$ & AVERAGE & SLOPED & STEEP & YES & RAISED & NONE & NONE & 2413 \\
\hline $\begin{array}{c}\text { Innermost } \\
\text { Gardens }\end{array}$ & AVERAGE & FLAT & STEEP & YES & GROUND & NONE & AVERAGE & 2000 \\
\hline $\begin{array}{c}\text { Island Bay/ } \\
\text { Berhampore } \\
\text { CO }\end{array}$ & GOOD & STEEP & SLOPED & YES & GROUND & GOOD & AVERAGE & 1335 \\
\hline Kai o Te Aro & AVERAGE & FLAT & FLAT & YES & RAISED & AVERAGE & POOR & 2531.64 \\
\hline Karori CG & GOOD & FLAT & FLAT & UNKNOWN & RAISED & GOOD & POOR & 0 \\
\hline $\begin{array}{c}\text { Mokai Kainga } \\
\text { GOOD }\end{array}$ & FLAT & 'SLOPED & UNKNOWN & $\begin{array}{c}\text { RAISED AND } \\
\text { GROUND }\end{array}$ & NONE & POOR & 0 \\
\hline Newtown CG & UNUSED & FLAT & SLOPED & YES & RAISED & POOR & POOR & 0 \\
\hline Te Kawakawa & GOOD & FLAT & STEEP & YES & RAISED & NONE & POOR & 884 \\
\hline
\end{tabular}




\begin{tabular}{|c|c|c|c|c|c|c|c|c|}
\hline $\begin{array}{c}\text { Thurleigh } \\
\text { Grove }\end{array}$ & POOR & STEEP & STEEP & NO & GROUND & AVERAGE & AVERAGE & 0 \\
\hline Kaicycle & GOOD & FLAT & FLAT & YES & GROUND & GOOD & POOR & 2300 \\
\hline
\end{tabular}

\section{Defining Data Assessments}

Assessment terms used within table $\mathrm{X}$ are clarified in here.

Garden condition:

Unused - gardening spaces are not growing anything at present.

Poor - garden condition is deteriorated, signs such as: dry ground and unwatered plants, overgrown plants, general mess in the gardens, run down facilities, lack of produce actually growing or produce grown or over ripe/rotting produce left on plants. Some or all of these features may be evident in a garden classified as poor condition.

Average - garden is overall in a usable condition, there may be some areas that are not well-kept, however the majority has been looked after. Produce is growing, and plants have generally bell been tended to. There may be general mess and wear and tear, typical of an outdoor site.

Good - garden is well up-kept and tidy, the majority of available planting space has been utilised and is not over grown. Equipment and facilities are in a usable and tidy condition. Mess around the garden may still be present but is minimal.

Most of the garden sites had a flat terrain, even if the surrounding terrain was not. Flat terrain sites may indicate that they are easier to manage or more appealing to gardening participants, as the gardens on flat sites tended to be in better condition than gardens on sloped or steep sloped sites.

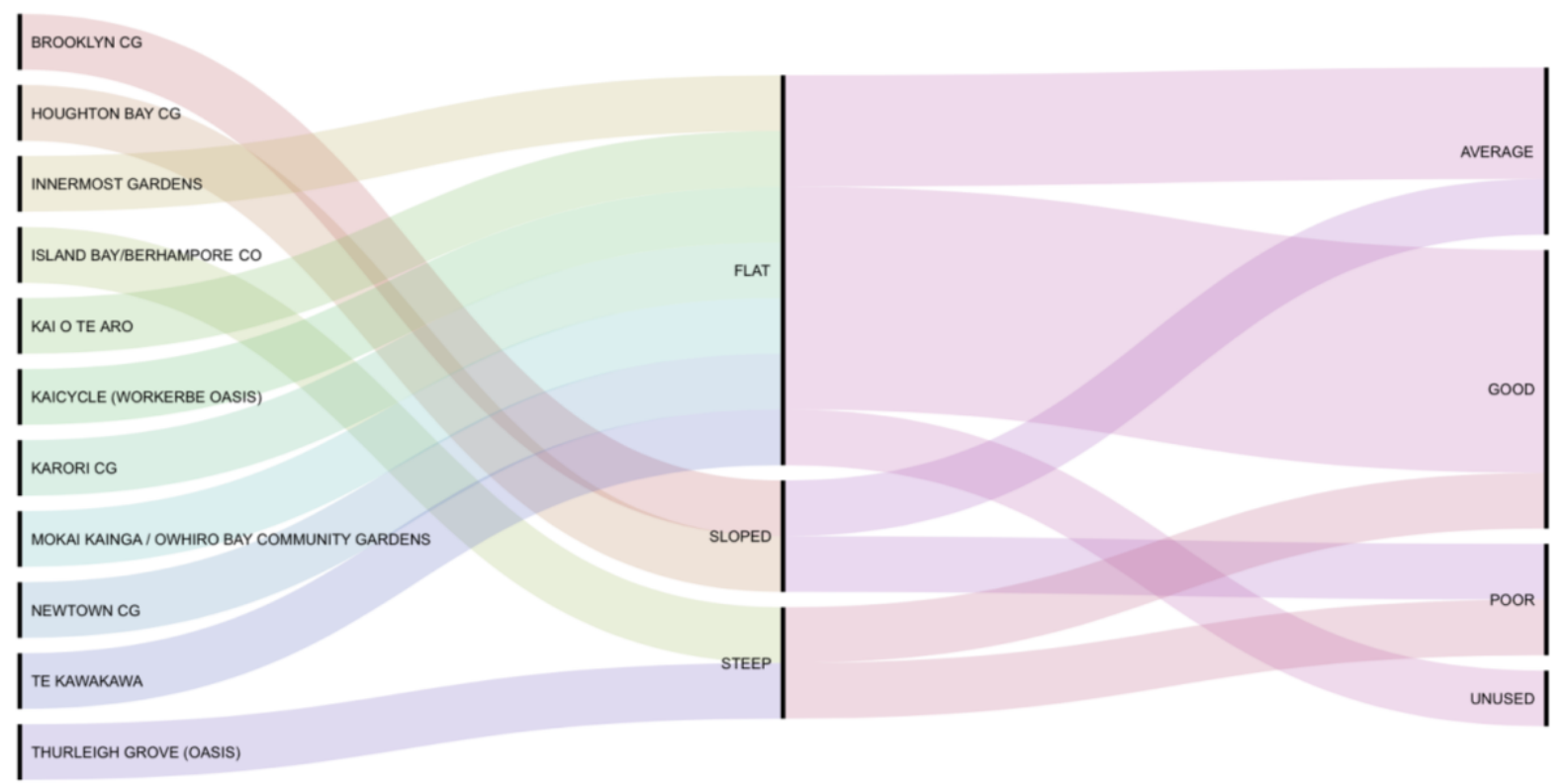

Figure 2: Garden vs terrain vs condition

Composting facilities are included in almost every garden, with

\section{Analysis of demographic trends in community garden neighbourhoods}

There is currently little research analysing the relationship between community population demographics and community gardens. It is currently unknown if there are trends where community gardens are 
occurring, and the type of people interested in pursuing the activity. In Wellington, this may be especially useful as gardens are initiated from a bottom-up approach. This could be useful for WCC to assess appropriate neighbourhoods that may adopt community gardening.

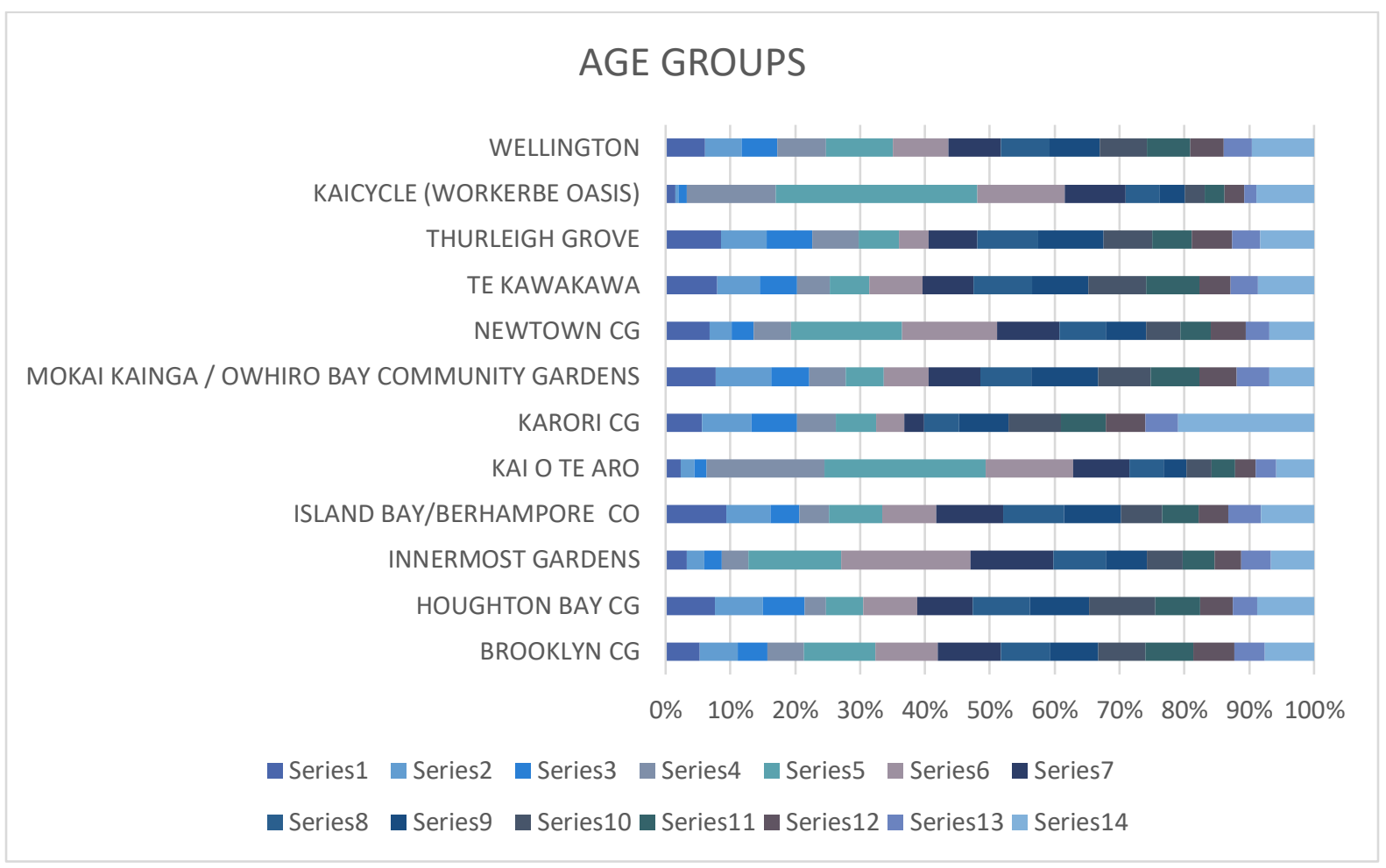

Figure 3: Percentage of population within age groups of community garden areas and Wellington

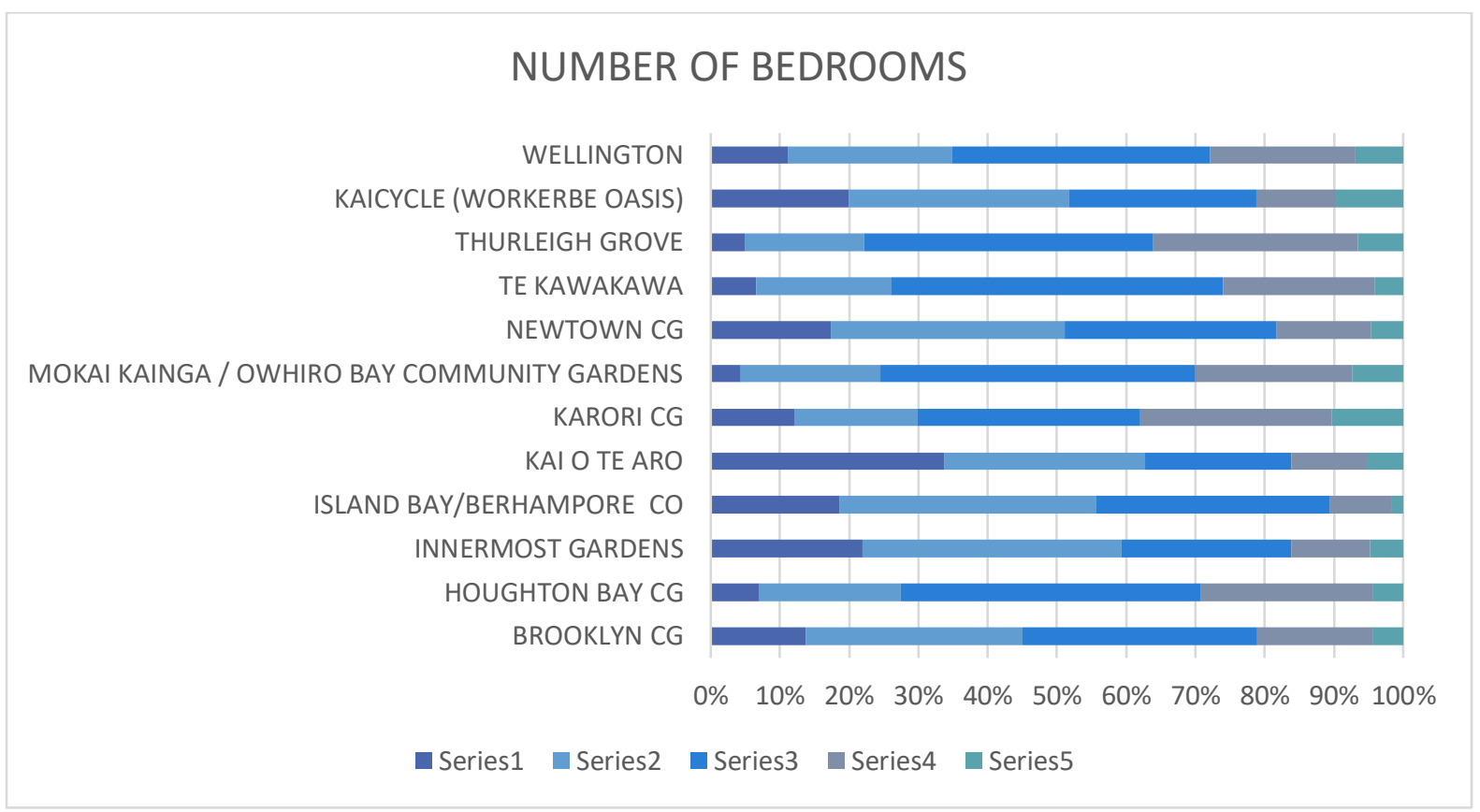

Figure 4: Percentage of number of bedrooms for dwellings in community garden areas and in Wellington

Number of bedrooms within occupied residential dwellings indicates how people are living in the area. As in figure three, it can be observed that in Wellington the there is a fairly even proportion of 2, 3- and 4bedroom homes, however community garden neighbourhoods tend to have more un-even proportions of these bedrooms. 


\section{FAMILY TYPES}

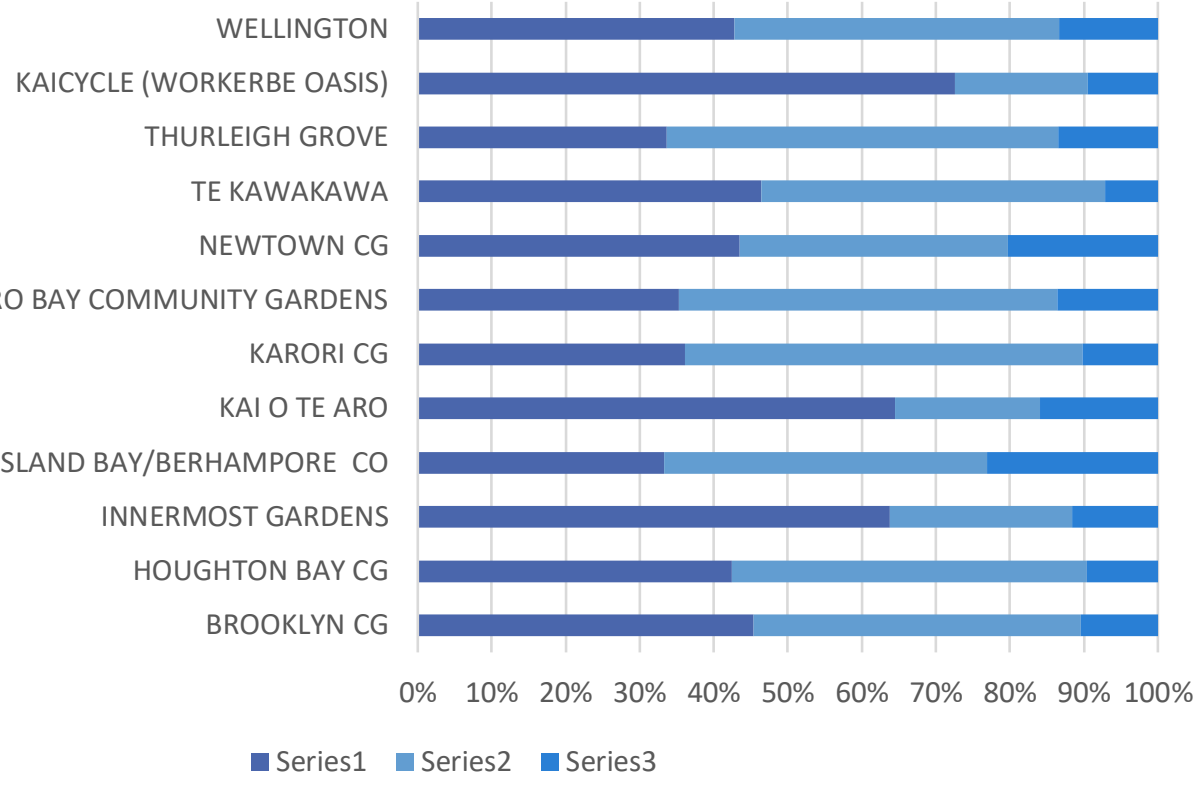

Figure 5

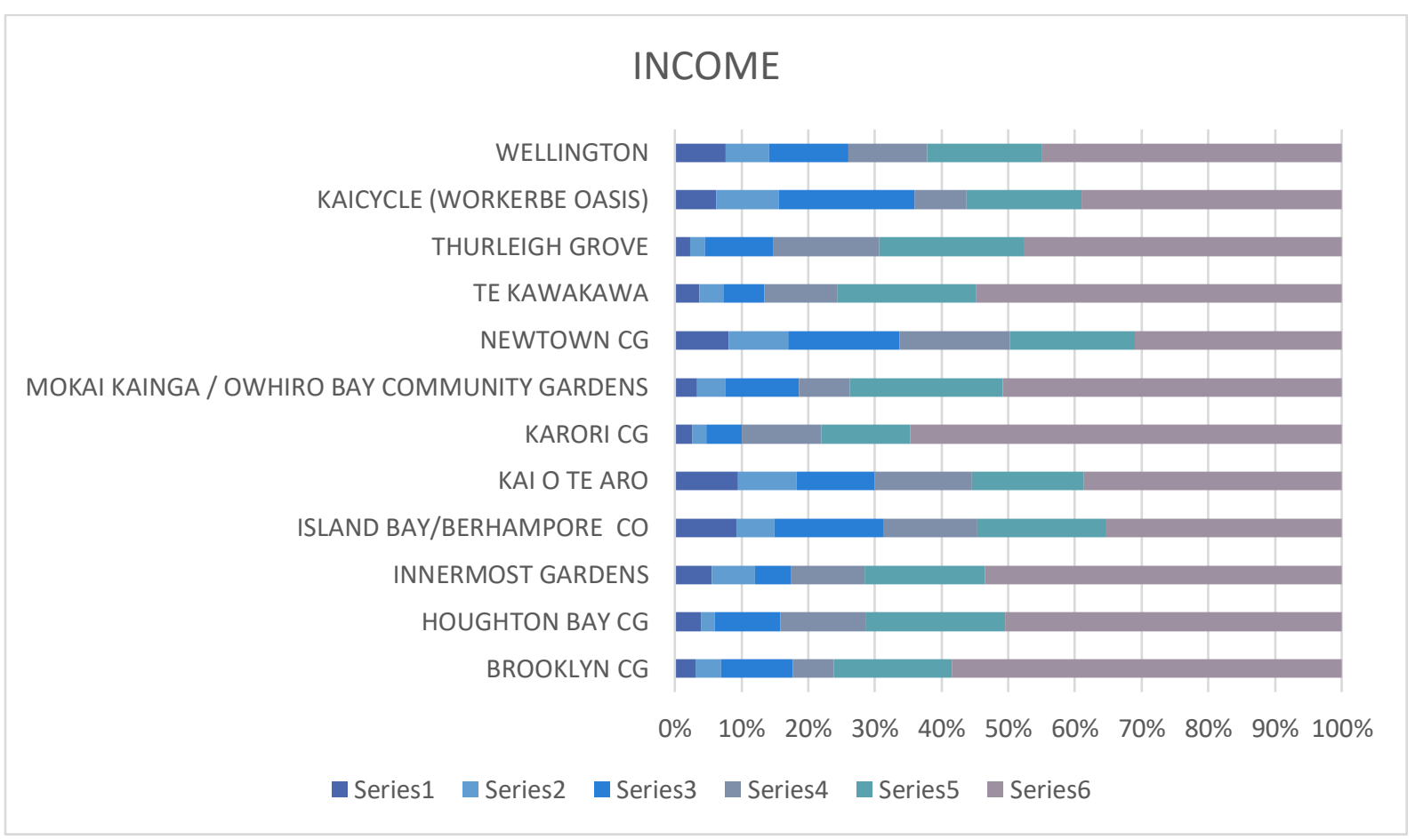

Figure 6 


\title{
EMPLOYMENT
}

\author{
WELLINGTON \\ KAICYCLE (WORKERBE OASIS) \\ THURLEIGH GROVE \\ TE KAWAKAWA \\ NEWTOWN CG
}

MOKAI KAINGA / OWHIRO BAY COMMUNITY GARDENS

KARORI CG

KAI O TE ARO

ISLAND BAY/BERHAMPORE CO

INNERMOST GARDENS

HOUGHTON BAY CG

BROOKLYN CG

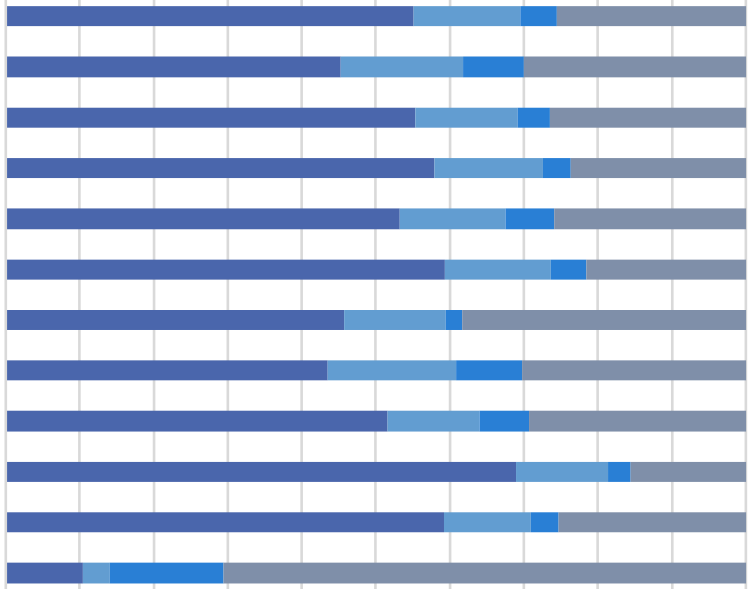

$\begin{array}{lllllllllllll}0 \% & 10 \% & 20 \% & 30 \% & 40 \% & 50 \% & 60 \% & 70 \% & 80 \% & 90 \% & 100 \%\end{array}$

- Series1 - Series2 a Series3 a Series4

Figure 7

Stats measured against garden attributes

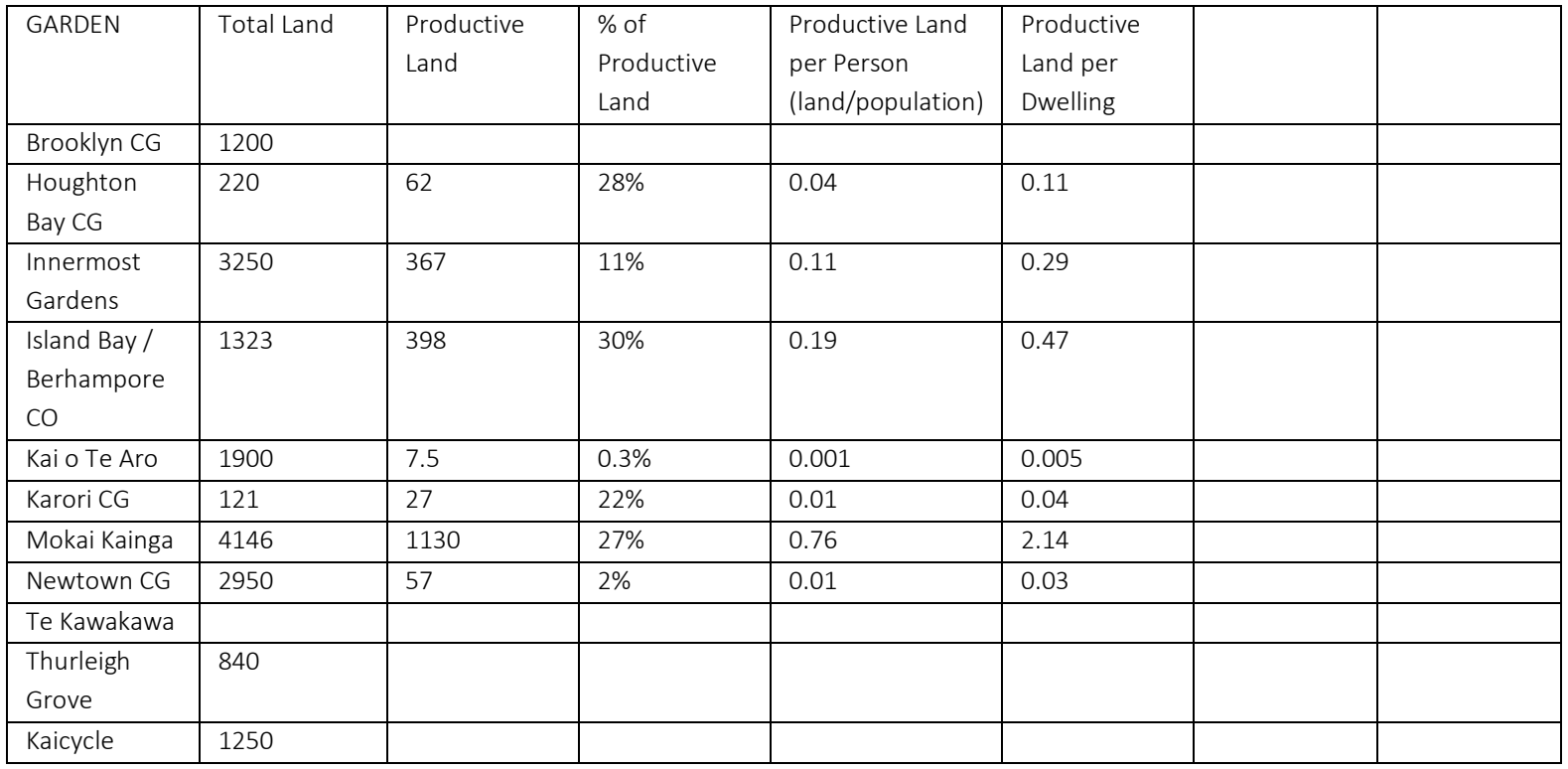

How are demographic pieces of data effecting the physical quality of the gardens? Are there dots to be joined that can identify links between a community type and a garden type?

Data that could have been there to improve the quality of the research that just isn't available

Volunteer numbers

Food production numbers 


\section{Design Guidance \& Recommendations}

\section{Updating Local Policy}

From this analysis, it is clear to see that community gardens within Wellington City are not realising their full potential, which may partially come down to local policy limitations. Considering Wellington's relatively short history of community gardening, but growth in popularity, it would be beneficial to update community garden guidelines and policy to further enable them. An updated local policy may include:

- $\quad$ An increase in funding budget to be able to support community garden ventures.

- Community garden initiated and supported by local government.

- Introduction of a community garden support role, who may have a combination of practical skills and management skills, to build the functions of existing and new gardens.

- $\quad$ Shifting governments perspectives on gardens from temporary ventures targeted at suffering communities to a long-term tool to increase food resilience in all communities.

- $\quad$ Reforming the idea of urban agriculture to be inclusive of all agricultural practices occurring in the urban scenario, and further assistance to intertwine this web.

with a bigger focus on design and maximising productivity.

New community garden guidelines should be reformed to promote community gardens as a viable strategy for food resilience, and include more tools to assist the design process and increase efficiency.

- Clearly defined terminology

- $\quad$ An outline of the variety of community garden approaches (typology and management), the where they are best suited

- $\quad$ A design guideline that is suggestive of scale, planning for efficiency

Guidance for different types of open spaces etc

More money allocation not just to gardens but the whole web of UA, and promotion of all that Stronger system in place to support UA

A landscape designer/someone with experience in the field to be a part of the design process of community gardens

WCC initated gardens in addition to community intiated

Even with guidelines in place, in a developed society there is still limited site selection and there will always be compromise

Even in new developments - you can lead a horse to water but you can't make it drink

No system in place to support our current UA 


\section{Limitations \& Further Research}

Due to the small pool of current research on community gardens, particularly nationally, and the limited data available in Wellington, this presents a large scope of research potential

Cencus 2013 Data dating

Lack of measurable values obtainable from WCC / lack of recorded data

Qualitative research to go with quantitative to overlay a different perspective

Assumptions?

One of the key limitations of the research was the dated cencus data. Although using cencus data was the best available option, it meant we were looking at communities in a time frame before that was disconnected from the current community gardens. Although communities move at a relatively slow rate of change (thus this data is still kinda valid) and this was the only data available... Once the 2018 cencus data becomes available, the next step for research may involve an updated review

Obtaining data on metrics such as food production and participation would be the most important next step in community garden research. Food production and participation are quantifiable measures of success which are currently not seen within local or international research.

Qualitative research into the perceptions, motives and would be another valuable addition to community garden research. This research concluded one of the key barriers to advancing community gardening was the misalignment of preceptions between all the parties involved in community gardening. If these perceptions were collected from a variety of characters - community gardeners, non-gardeners, garden managers, local government, funding groups, charitable trusts. If we could flesh out the various thoughts on community gardening it. An overlay of qualitative research with quantitative is an unexplored facet in the context of New Zealand community gardens.

Furthermore, another area of qualitative research may pertain to the management styles practiced within each of the Wellington community gardens. Without qualitative research it is unclear how each of the gardens are currently operating, and what management/operational model may be best working amongst them.

Another way to test policy's effect on community gardens would be to carry out a comparative study between gardens affiliated and not affiliated with Wellington city council.

Further research may go into more detail about how individual garden typologies fit within their communities and to be able to rank / list what garden typologies are best suited to a type of community. 